\title{
Modeling Land Use and Land Cover Dynamic Using Geographic Information System and Markov-CA
}

\author{
Millary Agung Widiawaty ${ }^{1}$, Arif Ismail ${ }^{1,2 *}$, Moh. Dede ${ }^{3}$, N. Nurhanifah ${ }^{1}$ \\ ${ }^{1}$ Department of Geography Education, Faculty of Social Sciences Education (FPIPS), \\ Universitas Pendidikan Indonesia, Bandung City, West Java, 40154, Indonesia \\ ${ }^{2}$ Study Program on Survey, Mapping and Geographic Information, Faculty of Social Sciences \\ Education (FPIPS),Universitas Pendidikan Indonesia, Bandung City, West Java, 40154, Indonesia \\ ${ }^{3}$ Master Program on Environmental Science, Postgraduate School (SPs), Universitas Padjadjaran, \\ Bandung City, West Java, 40132, Indonesia \\ *Corresponding Author : arifismail@upi.edu
}

Received 27 April 2020/Revised 30 June 2020 / Accepted 5 July 2020/ Available Online 12 July 2020

\begin{abstract}
The need for built-up area increases along with a rise in population growth in many regions. This phenomenon leads to a tremendous change in agricultural land and decrease in the environmental carrying capacity. Therefore, this study aims to determine Land Use and Land Cover (LULC) dynamics and the drivers used for its modeling in 2030. This is a quantitative study, which uses the dynamic models of Geographic Information System (GIS) and MarkovCA. Data were obtained from the CNES-Airbus satellite imageries in 2009, 2014, and 2019 by using Google Earth at East Cirebon. The drivers include road density, distance to CBD, total population, distance to settlements, land slope and distance to rivers. The interaction between drivers and LULC change was analyzed using binary logistic regression. The results showed that the rise of built-up area reached 36.4 percent and causes the loss of $0.78 \mathrm{~km}^{2}$ of agricultural land from 2009 to 2019. The LULC simulation in 2030 shows an increase in the built-up area by 82.85 percent with probabilities above 0.6 . Meanwhile the significant drivers for changes include road density and distance to settlements. In conclusion, efforts to reduce LULC change in agricultural land into built-up area is by re-strengthening spatial planningbased environmental awareness for the community.
\end{abstract}

Keywords: Built-up area; GIS; LULC; Markov-CA; Spatial modeling 


\section{Introduction}

Land is a valuable resource formed from biotic and abiotic components on the earth's surface (Asselen \& Verburg, 2013). Its various forms and uses are referred to as land use and land cover (LULC) (Aspinal \& Hill, 2008). Land growth rates and human needs have varying patterns, although it is a limited resources- its value typically appreciates over time. It has both direct and indirect impacts on humans which leads to the dynamic phenomenon of LULC, such as the transformation of agricultural land into built-up area (Gashaw et al., 2017).

This condition is caused by several factors or drivers, from the physical and social environment (Kusratmoko et al., 2017). In Indonesia, the rate of land conversion follows a linear pattern from 1.8 percent to 2.1 percent (BPS, 2013). There is an increase in the demand for built-up areas such as housing, amenities, infrastructure as well as employment in the industrial sector due to the 2030 demographic dividend. This led to the shrinkage of productive-agricultural lands that served as food barns. Cirebon is one of the regions which has agricultural comparative-advantage, as well as a similar pattern of LULC conversion (Dede et al., 2016; Dede et al., 2019). This is evident in the emergence of its Regional Planning (RTRW) from 2018 to 2038 and Regional Regulation on Sustainable Agricultural Land (LP2B), these two policies have the directives to protect 45,000 hectares of agricultural land against LULC change.

LULC change in the western region of Cirebon occurred due to industrialization, while in the Eastern part, it is caused by the development of new residential and industrial areas for numerous multinational companies. Another region that experiences this change is Gebang Sub-District. Its development is rapidly instigated by the local government because this region has poor economic growth than The Western Region of Cirebon. This actualization was realized by the residential and industrial projects carried out on lands formerly used for agricultural purposes. Assuming, the rate of LULC change is not properly controlled, it tends to cause several impacts as well as a decline on environmental carrying capacity (Hidajat et al., 2013). The factors that affects this phenomenon is geographically determined through an efficient method referred to as spatial modeling. Its dynamic nature is predicted using spatial modeling and geographic information system (GIS) subsequently, the use of vector and raster data based on remote sensing imageries is ideal for future purposes (Dan-Jumbo et al., 2018). An LULC spatial modeling relating to physical and social factors is capable of determining (didactic) and illustrating the dynamic process (heuristic) to produce useful outcomes for the regional development planning (Sanders, 2007; Kangalawe 
\& Lyimo, 2010). It is also used to evaluate the changes in probability, the influence of the factors or drivers, and dynamic scenario based on certain trends in space and time (Kumar et al., 2015).

Markov-Cellular automata (CA) is a dynamic spatial model composed of cells (pixels or grids), each of which is systematically arranged. It is also robust in predicting the transitions or spatial and temporal dynamics among a number of LULC types... 2014). This model is a computational method for determining dynamic systematic changes that depend on certain rules developed temporally (Liu, 2012). It functions in accordance with the principle of game play, it is sensitive to cell size, and neighborhood configuration or similar to three or more existent parcels (Moreno, 2008). Markov-CA, when compared with other dynamic models has advantages such as the ability of individuals to boost information that has under the regular principles, regulates their evaluation, and analysis of the spatial (space) characteristics, used to easily predict land use in the future (Gambo et al., 2018).

Knowledge of existing LULC changes and the probability of its dynamics in the future is important for regional development, particularly in rural areas proposed as growth centers such as Gebang District, and Cirebon Regency. Previous studies generally examined the LULC changes in critical watershed, peri-urban, metropolitan, and megapolitan regions (Lahti, 2008; Chavula et al., 2011; Li et al., 2019). Furthermore, the studies carried out in rural areas, primarily focuses on the use of land for agricultural purposes and forestry (Sodikin et al., 2018; Voight et al., 2019). According to previous studies, its factors or drivers tend to have an effect on the biogeophysical aspects rather than the regional socio-economic conditions. Therefore, efforts to examine LULC changes in rural areas with potentially significant landscapes are essential for adaptive and sustainable regional development policies. This study aims to determine the dynamics of LULC in Gebang District representing the Eastern Cirebon and the future application of GIS and Markov-CA models.

\section{Methods}

\subsection{Study Area}

This research was carried out at Gebang Sub-District, East Cirebon Regency, West Java. This area is situated between Cirebon, Kuningan and Brebes Regency. It has a tropical climate characterized by an average temperature of $32^{\circ}$ Celsius and annual rainfall of approximately 2000 to $2500 \mathrm{~mm}$. Gebang has an altitude of 0 to $37 \mathrm{~m}$ above sea level and the region is suitable for the cultivation of rice, pulses and sugarcane, however it is quite susceptible to flood and tidal rising. This study applied saturated sampling in 14 villages 
(Figure 1). Subsequently, LULC dynamic model is an input for environmental conservation as well as efforts to protect productive agricultural land.

\subsection{Data Acquisitions}

Basic information on LULC was obtained using the 2009 CNES-Airbus imagery which had a spatial resolution of 0.96 meters. The analysis of land changes were initiated based on a temporal span of 10 years which was due to the independent implementation of development policies in the region - in the early 2000s, Gebang was separated from Babakan. The second temporal (time) data was obtained with the 2014 CNES-Airbus imagery. Meanwhile, the first law of geography refers to the dynamics of LULC's spatial modeling which stated that everything is related, however those that are closer are more influential than distant things (Sui, 2004; de Smith et al., 2007; Foresman \& Luscombe, 2017). Consequently, all spatial phenomena are formed due to reciprocal relationships with their neighboring environment, which leads to geographical closeness that offers stronger and more influential interactions. This is common in cross-sectional phenomena such as land use, therefore the Markov-CA, is a suitable mathematical model (Hamad, et al., 2018; Hua, 2017).

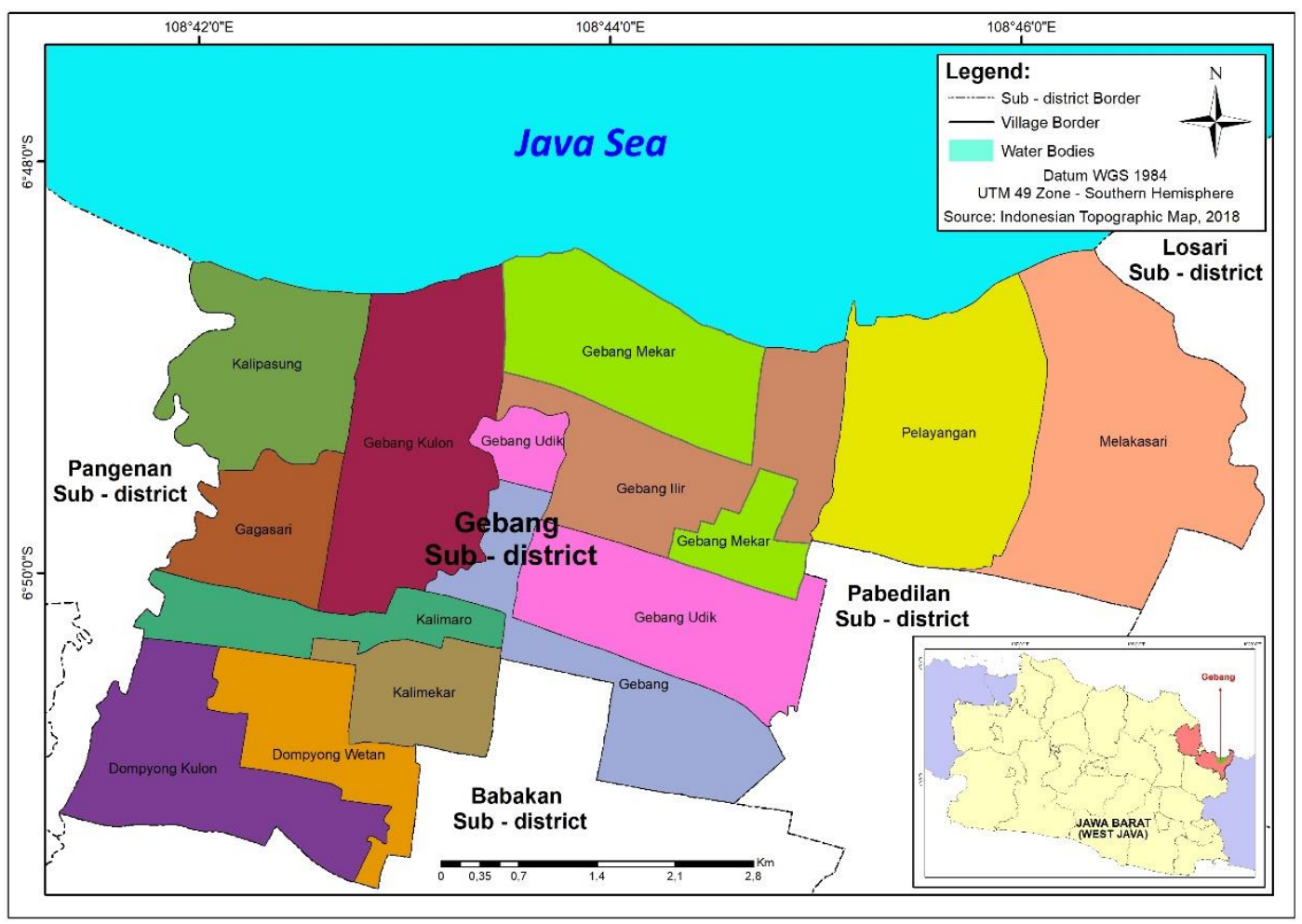

Figure 1. Study Area

This study utilized primary data obtained from field surveys carried out as part of testing land use in 2019, however secondary data was derived from reliable sources, namely 
scientific articles, official reports of government and non-governmental institutions (Table 1). These data are validated according to geospatial criteria in order to enable LULC dynamic spatial modeling.

Table 1. Data Acquisition and Research Variables

\begin{tabular}{|c|c|c|}
\hline Variable or driver & Data & Data acquisition \\
\hline Land slope $\left(\mathrm{X}_{1}\right)$ & Raster & ASTER DEM (2019) \\
\hline Distance to rivers $\left(\mathrm{X}_{2}\right)$ & Vector & $\begin{array}{l}\text { Field survey (2019) and buffering HOT-OSM } \\
\text { BNPB data (2019) }\end{array}$ \\
\hline Distance to $\mathrm{CBD}\left(\mathrm{X}_{3}\right)$ & Vector & Buffering based on field survey (2019) \\
\hline Total population $\left(\mathrm{X}_{4}\right)$ & Atribut & Indonesian Statistical Agency (BPS) (2019) \\
\hline Road density $\left(\mathrm{X}_{5}\right)$ & Vector & BIG Tanah Air-Geoportal (2019) \\
\hline Distance to settlements $\left(\mathrm{X}_{6}\right)$ & Vector & $\begin{array}{l}\text { Buffering based on visual-supervised classification } \\
\text { of CNES-Airbus (2019) }\end{array}$ \\
\hline Land use and land cover (Y) & Vector and raster & $\begin{array}{l}\text { Visual-supervised classification of CNES-Airbus } \\
\text { Imageries (2019) and field survey (2019) }\end{array}$ \\
\hline
\end{tabular}

\subsection{Data Analysis}

This research applied a quantitative approach for making interpretation and drawing inferences from changes in the dynamic system which occurs due to its drivers and the LULC predictions by the Markov-CA model. Supposing the outcome is combined with nonparametric statistical analysis, the determinants or drivers influencing this phenomenon are discerned (Quan et al., 2006; Deng et al., 2009). Therefore, the results from Markov-CA were combined with the logistic regression method to obtain the probability value in the modeling of LULC in Gebang (Equation 1). Logistic regression is defined as a type of nonparametric statistics, which involves the interaction between variables relating to an actual situation in the absence of classical assumption test. The modelsproduce potential LULC dynamics in the future. The probability of spatial dynamics is determined by the transformation of standardized $\mathrm{Z}$ values (Hosmer, 2013). Through this model, the intervention of independent variables that are highly significant produces several scenarios of LULC probabilities.

$\ln \left(\frac{\mathrm{p}}{1-\mathrm{p}}\right)=\alpha+\beta_{1} \mathrm{X}_{1}+\beta_{2} \mathrm{X}_{2}+\ldots+\beta_{\mathrm{n}} \mathrm{X}_{\mathrm{n}}$

where $\ln$ is the natural logaritmic, $\mathrm{p}$ probability value, $\alpha$ regression constant, and $\beta$ predictor coefficient.

The results from the validation of spatial modeling were obtained using data from ground truth which involves 30 LULC samples from all villages in Gebang Sub-District. This 
effort is evident in the overall accuracy and kappa values (as shown in Equation 2 and 3) (Widiawaty et al., 2018).

overall accuracy $=\frac{\mathrm{L}_{1}+\mathrm{L}_{2}+\ldots .+\mathrm{L}_{\mathrm{n}}}{\mathrm{n}}$

overall kappa $=\frac{\mathrm{OA}-\mathrm{EA}}{1-\mathrm{EA}}$

Where L is LULC types, $\mathrm{n}$ total samples, OA observed, and EA expected agreement.

\section{Results and Discussion}

The analysis of LULC dynamics started in 2009 because the study area showed the independent implementation of development policies after it was separated from Babakan Sub-District in the early 2000s. During this period LULC was dominated by agricultural land and salt-fisheries with an area of approximately $29.11 \mathrm{~km}^{2}$ (82.38 percent), other large proportion consist of built-up areas $\left(2.93 \mathrm{~km}^{2}\right)$ and plantations $\left(2.60 \mathrm{~km}^{2}\right)$. In 2014, the builtup area gained a significant increase of approximately $0.93 \mathrm{~km}^{2}$, five years later. However, various conditions caused a decline at the plantations and agricultural lands to relatively 0.26 $-0.58 \mathrm{~km}^{2}$ (as shown in Figure 2). In accordance with the aquacultural sector, there was a decline in areas utilized as salt-fisheries and they were transformed into mangrove forests due to lack of management.

It is assumed that the prediction of LULC information during the final periods are based on the interpretation and classification of imageries, obtained in 2019 and 2030 using GIS and Markov-CA model. The model used a redundant temporal dynamics with pixel resolution $5 \mathrm{~m}$ x 5 according to the geospatial regulation in Indonesia (Law 4/2011 of Geospatial Information). The LULC model has an overall accuracy of 93.33 percent and kappa of 0.92 , therefore it is valid and needs to be recommended for future purposes. The high-level of accuracy is considered prevalent due to the detection of LULC using high satellite imagery resolution with an accuracy of relatively 0.80 (Ustuner et al., 2017). The LULC model in 2019 showed several changes in built-up areas, furthermore its increase caused a decline in agricultural lands, plantation, etc (Figure 3). The occurrence of accretion led to the development of mangrove vegetation of approximately $0.02 \mathrm{~km}^{2}$. Sediment materials from Ci Beres and Ci Sanggarung accumulated in the shoreline of Gebang.

In 2030, Gebang Sub-District is expected to be highly-dynamic because the built-up areas was approximately 20.67 percent, tend to increase to $3.99 \mathrm{~km}^{2}$ due to the function of non-vegetated land and plantations with a probability of $0.43-0.45$. Changes in LULC were 
also detected in agricultural land and shrubs with a probability of relatively 0.10 as shown in Table 2. The direction of the dynamics in this region starts with the exhaustion of agricultural land which is converted to non-vegetated land till it is covered with marshes and woody plants. Initially, it was made up of agricultural land which gradually became compact and used to build settlements as well as other infrastructures to support human needs. This is common in various parts of the world to prevent subsidence thereby resulting in the conversion and utilization of inappropriate human activities to manage the environment (Minderhoud et al., 2018). Therefore, the agricultural land is directly converted to built-up areas. Figure 2 shows that agricultural land decrease every time.
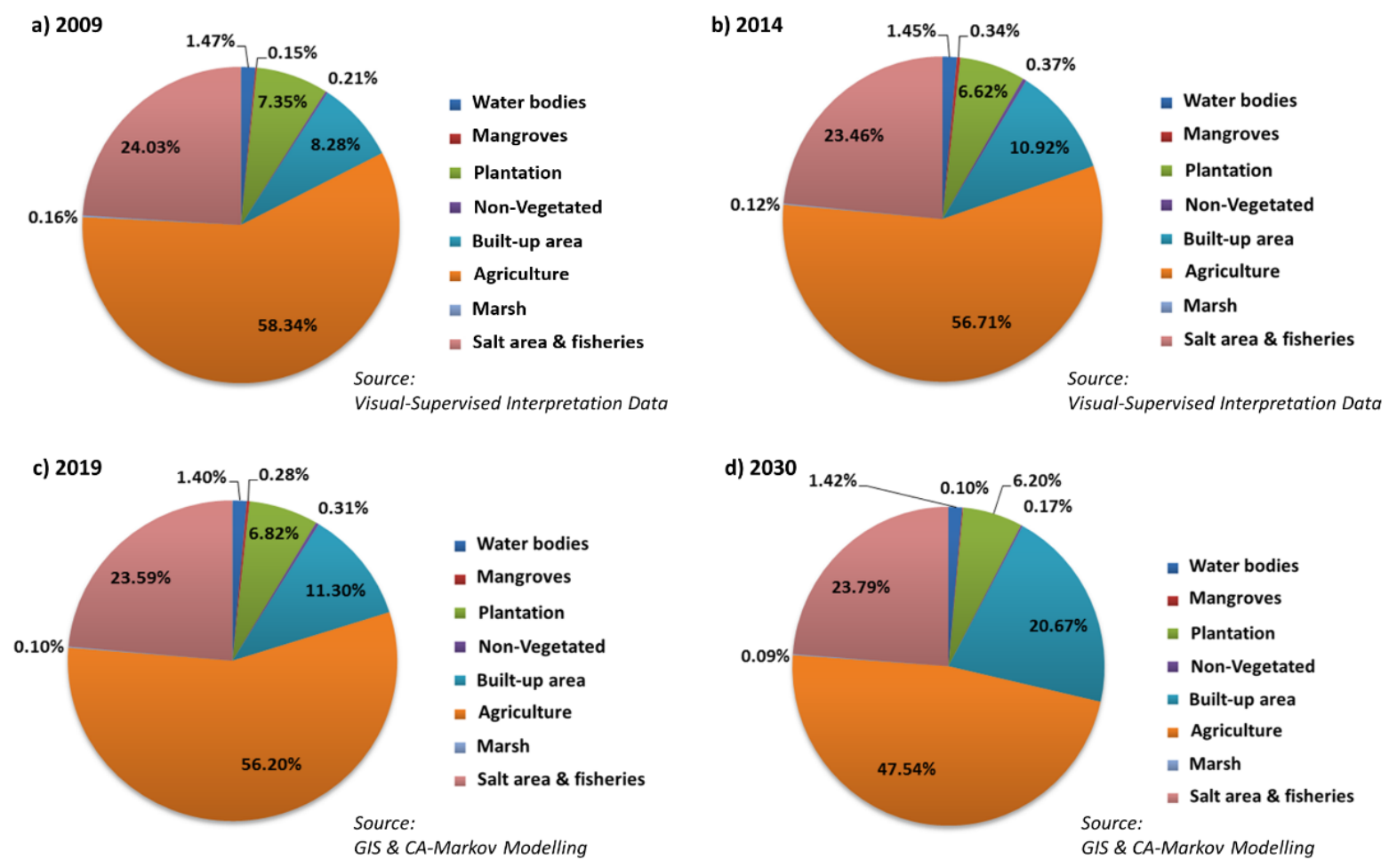

Figure 2. LULC Change in Gebang and Prediction in the Future

Table 2. LULC Change Probabilities

\begin{tabular}{lcccccccc}
\hline \multirow{2}{*}{\multicolumn{1}{c}{ LULC Type }} & \multicolumn{1}{c}{ Probability } \\
\cline { 2 - 9 } & WB & MA & Pt & NV & BA & AL & Mr & SF \\
\hline Water bodies (WB) & 0.322 & 0.049 & 0.171 & 0.002 & 0.114 & 0.089 & 0.023 & 0.231 \\
Mangroves (MA) & 0.182 & 0.029 & 0.047 & 0.003 & 0.038 & 0.029 & 0.008 & 0.666 \\
Plantations (Pt) & 0.029 & 0.002 & 0.346 & 0.001 & 0.447 & 0.167 & 0.002 & 0.007 \\
Non-vegetated (NV) & 0.015 & 0.005 & 0.042 & 0.009 & 0.437 & 0.162 & 0.001 & 0.331 \\
Built-up area (BA) & 0.021 & 0.001 & 0.090 & 0.000 & 0.870 & 0.015 & 0.001 & 0.002 \\
Agricultural land (AL) & 0.003 & 0.000 & 0.063 & 0.009 & 0.122 & 0.789 & 0.000 & 0.014 \\
Marsh (Mr) & 0.042 & 0.007 & 0.158 & 0.002 & 0.126 & 0.149 & 0.078 & 0.439 \\
Salt area \& Fisheries (SF) & 0.047 & 0.022 & 0.011 & 0.007 & 0.053 & 0.054 & 0.001 & 0.804 \\
Mean & 0.083 & 0.014 & 0.116 & 0.004 & 0.276 & 0.181 & 0.014 & 0.312 \\
\hline
\end{tabular}


LULC transition shows that human intervention in agricultural activities has the tendency to change the land into a built-up area. This condition is driven by lack and the pragmatic attitude of young people to become farmers - due to the fact that poverty aided in accelerating the rate of land conversion in the Cirebon Regency, particularly in Gebang District. The results from the gain and loss analysis show that the developed area was approximately $4.38 \mathrm{~km}^{2}$, while the agricultural land was reduced to $4.22 \mathrm{~km}^{2}$ as shown in Table 3. The LULC dynamics shows that a significant interaction exists between the decline in agricultural land and increase of built-up area. This pattern leads to food inequality because the human population continues to grow while there is a decline in agricultural lands, particularly in developing countries due to modernization and industrialization (Ouedraogo et al., 2010; Mhawish \& Saba, 2016). Figure 3 shows the expansion of built-up area in previous periods tends to be close to the road.
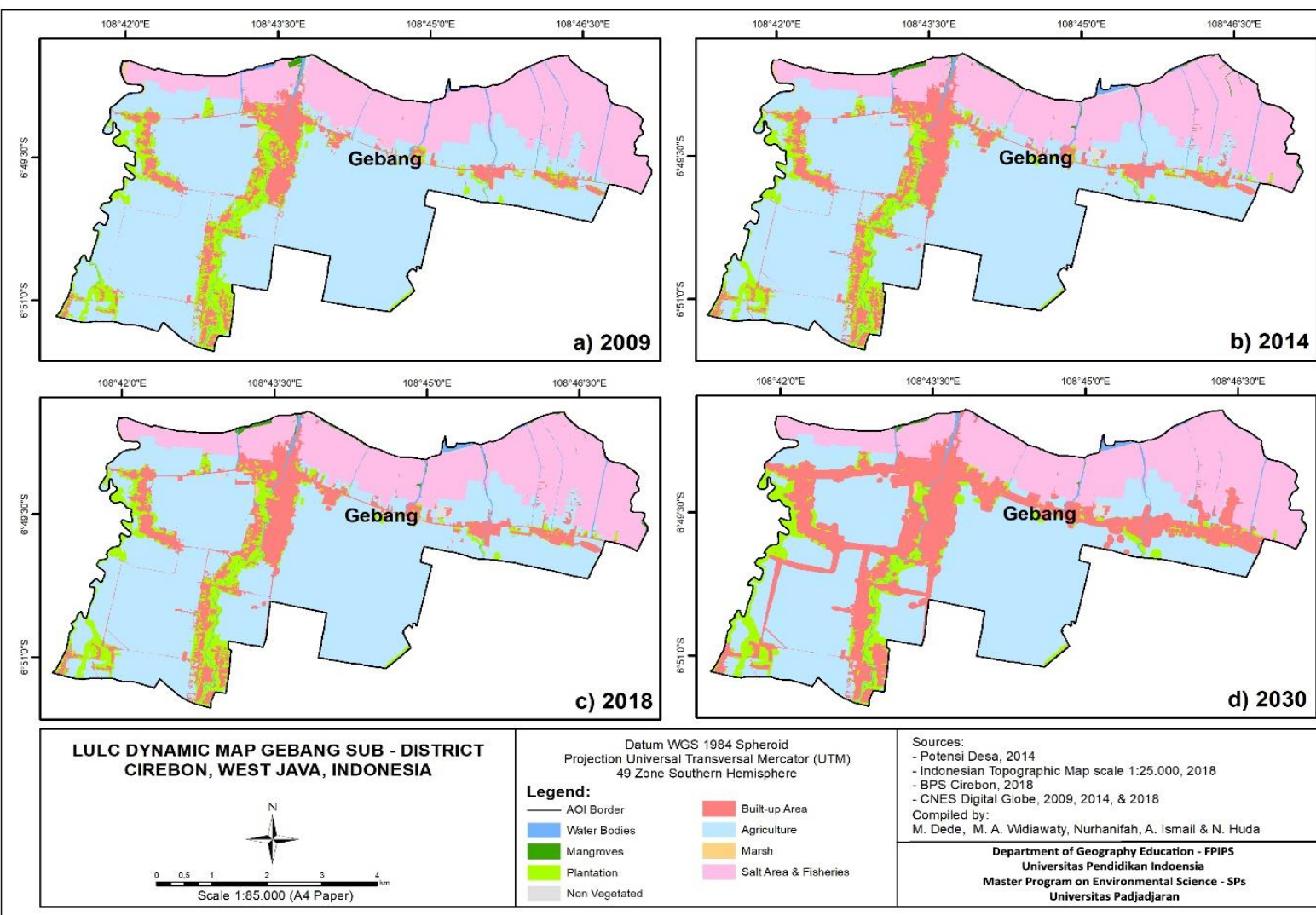

Figure 3. LULC Dynamic Map of Gebang

\subsection{Driven Factors of LULC Change}

LULC change in a dynamic system occurs due to various factors. The CA model produces predictions which combines with non-parametric statistical analysis useful in 
determining the various factors that influences this phenomenon referred to as drivers (Kamwi et al., 2018; Munthali et al., 2019). Therefore, the LULC modeling in Gebang SubDistrict is combined with the Markov-CA logistic regression methods to obtain the probability value of the dynamics. The testing involved 6 (six) factors or drivers known as independent variables namely land slope, distance to rivers, distance to $\mathrm{CBD}$, population, road density, and distance to the built-up area which were analyzed and reclassified as shown in Figure 4. LULC change is a dependent variable which consists of both changed and nonchanged lands.

a) Slope

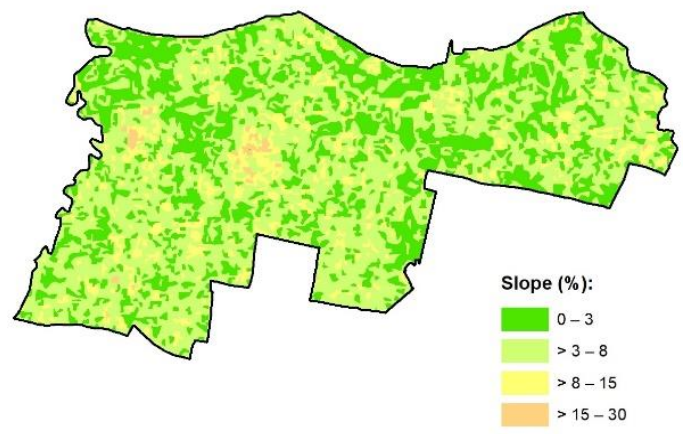

c) Distance to CBD

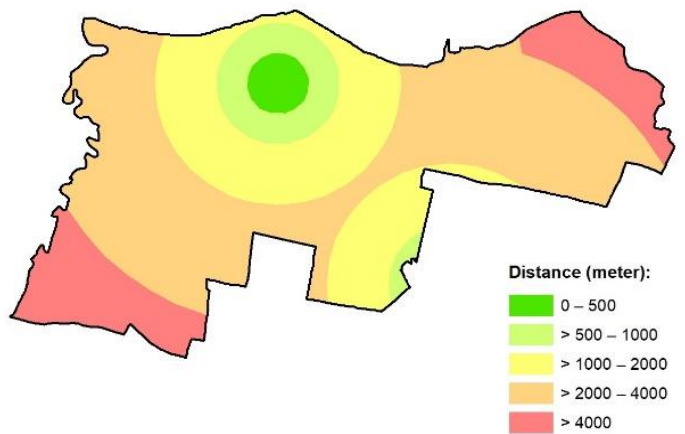

e) Road Density

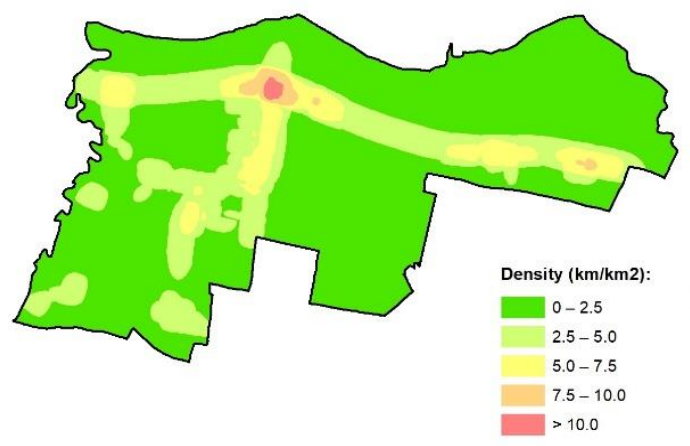

b) Distance to River

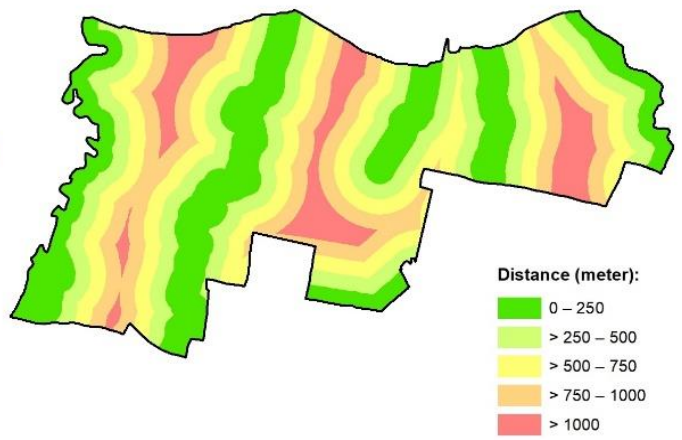

d) Population Number

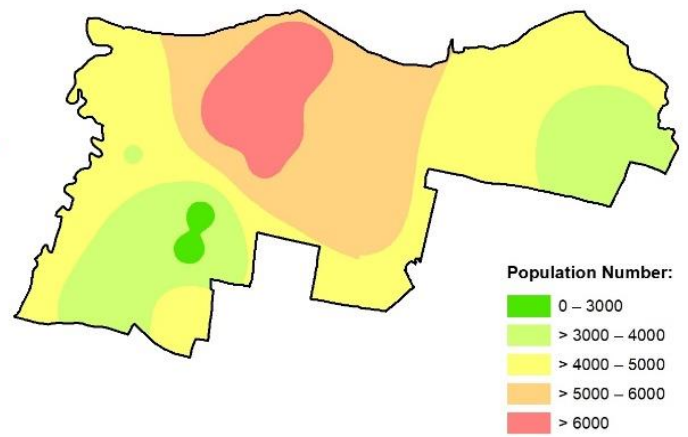

f) Distance to Built-up Area

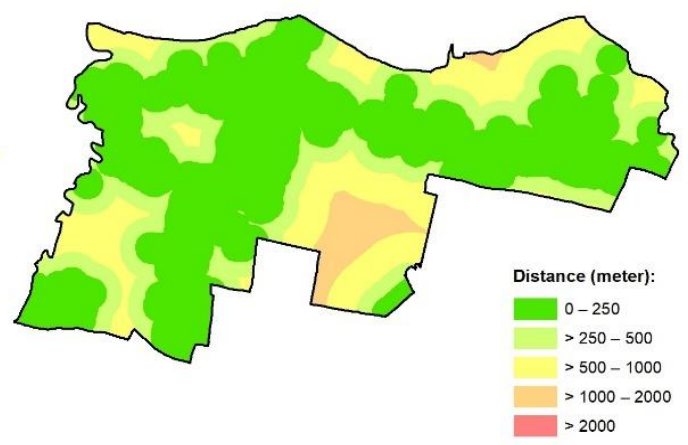

Figure 4. Drivers of LULC Changes 
Table 3. Gain and Loss All Types of LULC in Gebang

\begin{tabular}{lccccccccc}
\hline \multirow{2}{*}{\multicolumn{1}{c}{ LULC Type }} & \multicolumn{4}{c}{ Area $\left(\mathrm{km}^{2}\right)$} & \multicolumn{4}{c}{ Gain \& Loss (\%) } \\
\cline { 2 - 10 } & 2009 & 2014 & 2019 & 2030 & 2009 & 2014 & 2019 & 2030 \\
\hline Water bodies (WB) & 0.52 & 0.51 & 0.49 & 0.50 & - & -0.89 & -3.93 & 2.10 \\
Mangroves (MA) & 0.05 & 0.12 & 0.10 & 0.04 & - & 129.5 & -18.02 & -62.78 \\
Plantations (Pt) & 2.60 & 2.34 & 2.41 & 2.19 & - & -9.96 & 3.01 & -8.99 \\
Non-vegetated (NV) & 0.08 & 0.13 & 0.11 & 0.06 & - & 74.27 & -16.83 & -43.62 \\
Built-up area (BA) & 2.93 & 3.86 & 3.99 & 7.30 & - & 31.79 & 3.52 & 82.94 \\
Agricultural land (AL) & 20.6 & 20.0 & 19.9 & 16.8 & - & -2.78 & -0.92 & -15.36 \\
Marsh (Mr) & 0.05 & 0.04 & 0.03 & 0.03 & - & -25.46 & -14.99 & -3.59 \\
Salt area \& Fisheries (SF) & 8.49 & 8.29 & 8.34 & 8.41 & - & -2.36 & 0.54 & 0.86 \\
\hline
\end{tabular}

Table 4. Interaction between Drivers and LULC

\begin{tabular}{lcccc}
\hline \multicolumn{1}{c}{ Variable or driver } & $\mathrm{B}$ & $\operatorname{Exp}(\mathrm{B})$ & Sig. & Status \\
\hline Land slope $\left(\mathrm{X}_{1}\right)$ & 0.021 & 1.021 & 0.746 & Not significant \\
Distance to rivers $\left(\mathrm{X}_{2}\right)$ & 0.032 & 1.033 & 0.442 & Not significant \\
Distance to CBD $\left(\mathrm{X}_{3}\right)$ & -0.090 & 0.914 & 0.254 & Not significant \\
Total population $\left(\mathrm{X}_{4}\right)$ & -0.061 & 0.941 & 0.415 & Not significant \\
Road density $\left(\mathrm{X}_{5}\right)$ & 0.228 & 1.256 & 0.001 & Significant \\
Distance to settlements $\left(\mathrm{X}_{6}\right)$ & 1.776 & 5.907 & 0.000 & Significant \\
Constant & -8.647 & 0.000 & 0.000 & Significant \\
\hline
\end{tabular}

Table 5. LULC Dynamic Model Validity

\begin{tabular}{|c|c|c|c|c|c|}
\hline \multicolumn{6}{|c|}{ Model accuracy and drivers influence } \\
\hline \multicolumn{2}{|c|}{ Accuracy (percent) } & \multirow{2}{*}{\multicolumn{2}{|c|}{$\begin{array}{l}\text { Nagelkerke test } \\
\quad\left(\mathrm{r} \text { and } \mathrm{r}^{2}\right)\end{array}$}} & \multicolumn{2}{|c|}{ Significance } \\
\hline \multirow{2}{*}{$\begin{array}{c}\text { Without drivers } \\
50.2\end{array}$} & \multirow{2}{*}{$\begin{array}{c}\text { Using drivers } \\
66.0\end{array}$} & & & \multirow{2}{*}{$\begin{array}{c}\mathrm{p} \text {-value } \\
0.00\end{array}$} & \multirow{2}{*}{$\begin{array}{c}\mathrm{A} \\
0.05 \\
\end{array}$} \\
\hline & & 0.493 & 0.243 & & \\
\hline \multicolumn{6}{|c|}{ Goodness of fit (GoF) Hosmer-Lameshow } \\
\hline Chi-square value & Chi-square table & DoF & p-vaue & $\alpha$ & Status \\
\hline 10.61 & 15.51 & 8 & 0.225 & 0.05 & Fit \\
\hline \multicolumn{4}{|c|}{ Relative operative characteristics (ROC) } & & 0.73 \\
\hline
\end{tabular}

The result from logistic regression test implies that road density and distance to builtup area have a significant influence of approximately 95 percent confidence level (Table 4). This condition shows that the pattern of LULC changes tends to be close to the existing builtup area which has quality accessibility (Saputra \& Lee, 2019). In addition, six drivers simultaneously have a significant influence on LULC change, the r-value obtained from the 
Nagelkerke test is0.493, and an increase was detected in the value of Markov-CA based on GoF and ROC (as shown in Table 5). However, LULC changes also occur without influencing the drivers. This is evident in the 0.757 value of the epsilon which shows that other factors such as socio-economic conditions and political policies also influences the LULC preferences (Yirsaw et al., 2017). The interaction value between the drivers and LULC change in the regression model is shown in Equation 4.

The statistical results also known as the drivers of socio-economic aspects are more influential than the biogeophysical aspects in Gebang. These are certainly different from previous studies which stated that slope and distant water bodies are significant drivers (Hassen \& Assen, 2017; Dibaba et al., 2020). This shows that abrupt knowledge of the socioeconomic condition is necessary in the analysis of LULC change, although the nature of these drivers tends to be dynamic and difficult because they are the two main causes of urbanization - in the context of the development of rural and urban landscape (Han et al., 2015).

\subsection{Probability LULC in 2030}

The values of the input independent variable (drivers) stated in Equation 4 predicts the probability of LULC change in 2030. Out of the six drivers, four of them are constant namely slope, distances to the river, built-up area, and CBD. Therefore, the spatial probability of LULC in Gebang is only affected by two dynamic drivers namely population number and road density which are both significant variables. Population number in 2030 is obtained from the prediction of the population growth from 2009 to 2019. Gebang Sub-District has a population growth of 1.42 percent per year, therefore in 2030 it is predicted to be 67,449 people (approximately 10.77 percent). The increasing road density in 2030 is derived from the national average road development which is relatively 0.12 percent per year (Istiono, 2014). The results from processing and inputting data for the drivers into a logistic regression equation produced a probability scenario of LULC change as shown in Figure 5. This pattern of change is similar to the research carried out by Mienmany (2018) which predicts that almost all types of LULC have a potential change towards the built-up area.

In 2030, the probability of LULC change is predicted to be high in four villages Gebang Kulon, Gebang Ilir, Gebang Mekar, and Gebang Udik. These areas are close to the Gebang CBD and have high density, due to the influence of national arterial roads (pantura). Its existence offers a variety of socio-economic benefits for the population due to the role of 
interregional interaction, and the presence of built-up areas (McAndrews et al., 2017; Yesuph \& Dagnew, 2019). The total area of $0.55 \mathrm{~km}^{2}$ has a probability of approximately 0.4 . This value is smaller when compared to the land probability of $0.001-0.1$ with an area of 3.06 $\mathrm{km}^{2}$, irrespective of the changes.
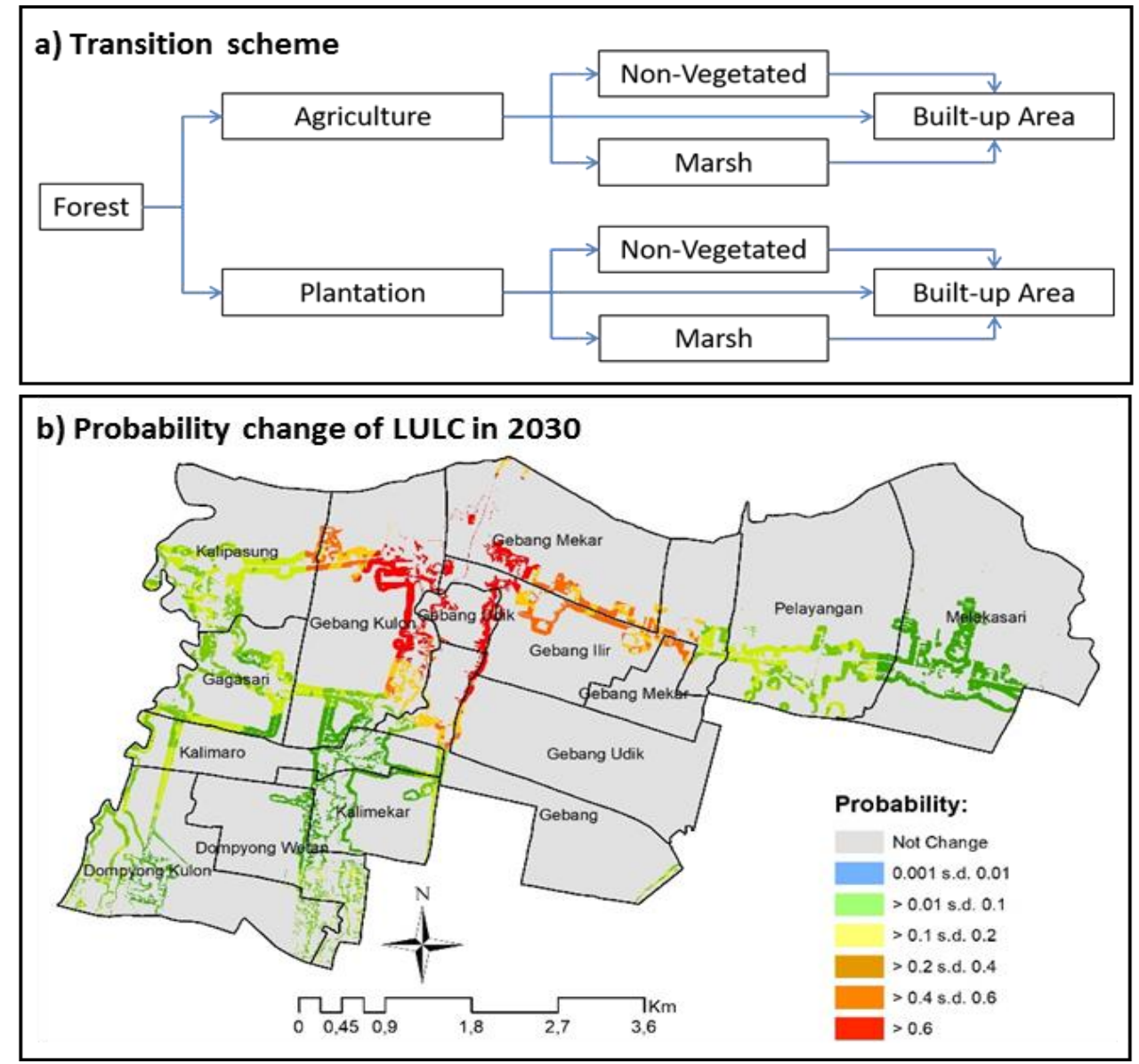

Figure 5. a) Pattern of LULC Change Transition and b) Probability Change of LULC Gebang in 2030

\section{Conclusion}

The integration of GIS and Markov-CA led to the emergence of a dynamic LULC model and information on various factors which influenced its changes in the Gebang SubDistrict. This research discovered that from 2009 to 2030 there tends to be an increase in built-up area accompanied by a decline in agricultural land and plantations. The predictions of 2030 also showed that the developed area was expanded to approximately 20.67 percent, while the largest land loss of relatively 18.5 percent occurred in agricultural land. Two drivers that have significant influence on LULC change is road density and distance to built- 
up area. In addition, the total chances of LULC occurrence in this region was approximately $4.31 \mathrm{~km}^{2}$.

\section{Conflict of Interest}

The authors declare that there is no conflict of interest with any financial, personal, or other relationships with other people or organizations related to the material discussed in the article.

\section{Acknowledgements}

This research is part of spatial dynamic project which were supported by FPIPS Univesitas Pendidikan Indonesia (UPI). The authors are grateful to Dr. Iwan Setiawan (head of SPIG Program, Department of Geography Education, FPIPS-UPI) and Nurul Huda (math teacher of SMA Negeri 1 Babakan, Cirebon Regency) for their various contributions.

\section{References}

Aspinall, R. J. \& Hill, M. C. (2008). Land Use Change, Science, Policy and Management. New York: Taylor \& Francis.

Asselen, S. \& Verburg, P. H. (2013). Land cover change or landuse intensification, simulating land system change with a global scale land change model. Global Change Biology, 19(12): 3648-3667.

BPS. (2013). Proyeksi Penduduk Indonesia 2010-2035. Jakarta: BPS.

Chavula, G., Brezonik, P. \& Bauer, M. (2011). Land use and land cover change (LULC) in the Lake Malawi Drainage Basin 1982-2005. International Journal of Geosciences, 2 (2): 172-178.

Dan-Jumbo, N. G., Metzger, M. J. \& Clark, A. P. (2018). Urban land-use dynamics in the Niger delta: the case of Greater Port Harcourt watershed. Urban Science, 2(4): 1-24.

de Smith, M. J. (2007). Geospatial analysis: a comprehensive guide to principles, techniques and software tools. Leicester: Troubador Publishing.

Dede, M., Sahidin, R. B. S., Yutika, M. \& Ramadhan (2016). Analisis potensi perekonomian sektor pertanian, kehutanan, dan perikanan serta pertambangan dan penggalian di Pantura Jawa Barat. Prosiding Seminar Nasional Epicentrum Geografi, 5.5: 100-108.

Dede, M., Widiawaty, M. A., Pramulatsih, G. P., Ismali, A., Ati, A. \& Murtianto, H. (2019). Integration of participatory mapping, crowdsourcing and geographic information system in flood disaster management (case study Ciledug Lor, Cirebon). Journal of Information Technology and Its Utilization, 2(2): 44-47. 
Deng, J. S., Wang, K., Hong, Y. and Jia, G. Q. (2009). Spatio-temporal dynamics and evolution of land use change and landscape pattern in response to rapid urbanization. Landscape and Urban Planning, 92(3): 187-198.

Dibaba, W. T., Demissie, T. A., \& Miegel, K. (2020). Drivers and implications of land use/land cover dynamics in finchaa catchment, northwestern ethiopia. Land, 9(4) doi:10.3390/land9040113.

Foresman, T., \& Luscombe, R. (2017). The second law of geography for a spatially enabled economy. International Journal of Digital Earth, 10(10), 979-995. doi:10.1080/17538947.2016.1275830.

Gambo, J., Shafri, H. Z. M., Shaharum, N. S., Abidin, F. A. \& Rahman, M. T. (2018). Monitoring and predicting land use-land cover (LULC) changes within around Krau Wildlife Reserve (KWR) protected area in Malaysia using multi-temporal Landsat data. Geoplanning: Journal of Geomatics and Planning, 5(1): 17-34.

Gashaw, T. (2017). Evaluation and prediction of land use/land cover changes in the Andassa watershed, Blue Nile Basin, Ethiopia. Environmental Systems Research, 6(17): 1-15.

Hamad, R., Balzter, H., \& Kolo, K. (2018). Predicting land use/land cover changes using a CA-markov model under two different scenarios. Sustainability (Switzerland), 10(10) doi:10.3390/su10103421.

Han, H., Yang, C., \& Song, J. (2015). Scenario simulation and the prediction of land use and land cover change in beijing, china. Sustainability (Switzerland), 7(4), 4260-4279. doi:10.3390/su7044260.

Hassen, E. A. \& Assen, M. (2017). Land use/cover dynamics and its drivers in Gelda catchment, Lake Tana watershed, Ethiopia. Environ. Syst. Res., 6 (4): 1-13.

Hidajat, M., Sitorus, S. R. P. \& Rustiadi, E. (2013). Urban sprawl effect on settlement areas in urban fringe of metropolitan area. Journal of Environment and Earth Science, 12(3): 172-179.

Hosmer, D. (2013). Applied Logistic Regression. New Jersey: John Wiley \& Sons.

Hua, A. K. (2017). Application of ca-markov model and land use/land cover changes in Malacca river watershed, Malaysia. Applied Ecology and Environmental Research 15(4): 605-622.

Istiono. (2014). Perubahan Perilaku Pengguna Jalan yang Berkeselamatan (Safer Road Users) Guna Menekan Tingkat Kecelakaan. Jakarta: The Indonesian Center for Police and Security Studies.

Kamwi, J. M., Cho, M. A., Kaetsch, C., Manda, S. O., Graz, F. P. \& Chirwa, P. W. (2018). Assessing the spatial drivers of land use and land cover change in the protected and communal areas of the Zambezi Region, Namibia. Land, 7(131): 1-13. 
Kangalawe, R. Y. M \& Lyimo, J. G. (2010). Population dynamics, rural livelihoods and environmental degradation: some experiences from Tanzania. Environment, Development and Sustainability, 12(6): 985-997.

Kumar, K. S., Valasala, N. V. A., Subrahmanyam, J. V. V., Mallampati, M., Shaik, K. \& Ekkirala, P. (2015). Prediction of future land use land cover changes of Vijayawada City using remote sensing and GIS. International Journal of Innovative Research in Advanced Engineering, 3(2): 91-97.

Kusratmoko, E. (2017). Modelling land use/cover changes with Markov-cellular automata in Komering watershed, South Sumatera. IOP Conf. Series: Earth and Environmental Science, 54(17): 5-8.

Lahti, J. (2008). Modelling Urban Growth Using Cellular Automata: A Case Study of Sydney, Australia. Master Thesis. International Institute for Geo-Information Science and Earth Observation, Enschede, The Netherlands.

Li, S., Yang, H., Lacayo, M., Liu, J., \& Lei, G. (2018). Impacts of land-use and land-cover changes on water yield: A case study in jing-jin-ji, china. Sustainability (Switzerland), 10(4) doi:10.3390/su10040960.

Liu, Y. (2012). Modelling sustainable urban growth in a rapidly urbanising region using a fuzzy constrained cellular automata approach. International Journal of Geographical Information Science, 26(1): 151-167.

McAndrews, C., Pollack, K. M., Berrigan, D., Dannenberg, A. L. \& Christopher, J. (2017). Understanding and improving arterial roads to support public health and transportation goals. American Journal of Public Health, 107(8): 1278-1282.

Mhawish, Y. M. \& Saba, M. (2016). Impact of population growth on land use changes in Wadi Ziqlab of Jordan between 1952 and 2008. International Journal of Applied Sociology, 6(1): 7-14.

Mienmany, B. (2018). Analysis of Land Use and Land Cover Changes and the Driving Forces:a Case Study in Kaysone Phomvihan District, Laos. Master Thesis. Faculty of Arts, Universidade do Porto, Portugal.

Minderhoud, P. S. J., Coumou, L., Erban, L. E., Middelkoop, H., Stouthamer, E. and Addink, E. A. (2018). The relation between land use and subsidence in the Vietnamese Mekong delta. Sci. Total Environ., 634: 715-726.

Moreno, N. L. (2008). A Vector-Based Geographical Cellular Automata Model to Mitigate Scale Sensitivity and to Allow Objects Geometric Transformation. PhD Thesis. University of Calgary.

Munthali, M. G., Davis, N., Adeola, A. M., Botai, J. O., Kamwi, J. M., Chisale, H. L. W., \& Orimoogunje, O. O. I. (2019). Local perception of drivers of land-use and land- cover change dynamics across dedza district, central malawi region. Sustainability (Switzerland), 11(3) doi:10.3390/su11030832. 
Ouedraogo, I., Tigabu, M., Savadogo, P., Compaoré, H., Oden, P. C. \& Ouadba, J.M. (2010). Land cover change and its relation with population dynamics in Burkina Faso, West Africa. Land Degradation \& Environment, 21(5): 453-462.

Quan, B., Chen, J. F., Qiu, H. L., Romkens, M. J. M., Yang, X. Q., Jiang, S. F. \& Li, B. C. (2006). Spatial-temporal pattern and driving forces of land use changes in Xiamen. Pedosphere, 16(4): 477-488.

Sanders, L. (2007). Model in Spatial Analysis. London: ISTE, Ltd.

Saputra, M. H., \& Lee, H. S. (2019). Prediction of land use and land cover changes for north sumatra, indonesia, using an artificial-neural-network-based cellular automaton. Sustainability (Switzerland), 11(11) doi:10.3390/su11113024.

Sodikin, Sitorus S. R. P., Prasetyo L. B. \& Kusmana C. (2017). Spatial analysis of mangrove deforestation and mangrove rehabilitation directive in Indramayu Regency, West Java, Indonesia. AACL Bioflux, 10(6):1654-1662.

Sui, D. Z. (2004). Tobler's first law of geography: a big idea for small world?. Annals of the Association of American Geographers, 94(2): 269-277.

Ustuner, M., Sanli, F. B. \& Dixon, B. (2017). Application of support vector machines for landuse classification using high-resolution RapidEye images: a sensitivity analysis. European Journal of Remote Sensing, 48(1): 403-422.

Voight, C., Hernandez-Aguilar, K., Garcia, C., \& Gutierrez, S. (2019). Predictive modeling of future forest cover change patterns in southern belize. Remote Sensing, 11(7) doi:10.3390/rs11070823.

Widiawaty, M. A., Dede, M. \& Ismail, A. (2018). Analisis tipologi urban sprawl di Kota Bandung menggunakan sistem informasi geografis. Seminar Nasional Geomatika, 3:547-554.

Yesuph, A.Y. \& Dagnew, A.B. (2019). Land use/cover spatiotemporal dynamics, driving forces and implications at the Beshillo catchment of the Blue Nile Basin, North Eastern Highlands of Ethiopia. Environ. Syst. Res., 8(21): 1-30.

Yirsaw, E., Wu, W., Shi, X., Temesgen, H., \& Bekele, B. (2017). Land Use/Land cover change modeling and the prediction of subsequent changes in ecosystem service values in a coastal area of china, the su-xi-chang region. Sustainability (Switzerland), 9(7) doi:10.3390/su9071204. 